\title{
Assessing Economic Resources in Retirement: The Role of Irregular Withdrawals from Tax-Advantaged Retirement Accounts
}

Michael D. Hurd and Susann Rohwedder

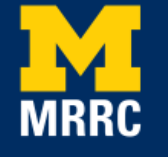

Project \#: R-UM18-Q4 


\title{
Assessing Economic Resources in Retirement: The Role of Irregular Withdrawals from Tax-Advantaged Retirement Accounts
}

\author{
Michael D. Hurd \\ RAND \\ Susann Rohwedder \\ RAND
}

October 2018

\author{
Michigan Retirement Research Center \\ University of Michigan \\ P.O. Box 1248 \\ Ann Arbor, MI 48104 \\ www.mrrc.isr.umich.edu
}

(734) 615-0422

\section{Acknowledgements}

The research reported herein was performed pursuant to a grant from the U.S. Social Security Administration (SSA) funded as part of the Retirement Research Consortium through the University of Michigan Retirement Research Center Award RRC08098401-10. The opinions and conclusions expressed are solely those of the author(s) and do not represent the opinions or policy of SSA or any agency of the federal government. Neither the United States government nor any agency thereof, nor any of their employees, makes any warranty, express or implied, or assumes any legal liability or responsibility for the accuracy, completeness, or usefulness of the contents of this report. Reference herein to any specific commercial product, process or service by trade name, trademark, manufacturer, or otherwise does not necessarily constitute or imply endorsement, recommendation or favoring by the United States government or any agency thereof.

Regents of the University of Michigan

Michael J. Behm, Grand Blanc; Mark J. Bernstein, Ann Arbor; Shauna Ryder Diggs, Grosse Pointe; Denise Ilitch, Bingham Farms; Andrea Fischer Newman, Ann Arbor; Andrew C. Richner, Grosse Pointe Park; Ron Weiser, Ann Arbor; Katherine E. White, Ann Arbor; Mark S. Schlissel, ex officio 


\title{
Assessing Economic Resources in Retirement: The Role of Irregular Withdrawals from Tax-Advantaged Retirement Accounts
}

\begin{abstract}
Irregular withdrawals from IRAs and DC pensions are not included in standard measures of household income in the CPS or Health and Retirement Study. Yet, among retirees such withdrawals can supplement regular retirement income to finance consumption. It has been difficult to assess their importance, because of lack of informative survey data. In 2012 the HRS restructured the way it collects information about pensions, improving the measurement of irregular withdrawals from pension accounts. We analyzed HRS 2014 data and found that irregular withdrawals from pensions and IRAs totaled $\$ 2,049$ for singles and $\$ 6,663$ for couples averaged over everyone age 55 and older. These irregular withdrawals amount to about 5 percent of income for singles and 10 percent of income for married households. Irregular withdrawals are highest among those in the highest wealth quartile and those in the highest education group, reflecting the higher prevalence of pensions in high-paying jobs that are predominantly held by those with high education. Because of the greater frequency of IRA and pension withdrawals towards high SES individuals, accounting for them has little impact on estimates of the poverty rate.
\end{abstract}

\section{Citation}

Hurd, Michael D. and Susann Rohwedder. 2018. "Assessing Economic Resources in Retirement: The Role of Irregular Withdrawals from Tax-Advantaged Retirement Accounts," Ann Arbor MI: University of Michigan Retirement Research Center (MRRC) Working Paper, WP 2018-387. https://mrdrc.isr.umich.edu/publications/papers/pdf/wp387.pdf

\section{Authors' acknowledgements}

Colleen McCullough and Jessica Hayes provided excellent programming assistance. 


\section{Introduction}

People save during their working lives to finance consumption in retirement. An important part of the saving is tax-advantaged saving accounts such as defined benefit (DB) pensions, defined contribution (DC) pension accounts, IRAs, and Keoghs. Several important policy questions are associated with such savings. First, when these plans are fully accounted for, how well are retirees economically prepared for retirement? Second, what is the contribution of these plans to economic preparation? This question is of considerable importance given the large tax costs of their provision. Third, who benefits from these plans? In particular, how well do they help those in the lower part of the income distribution meet the challenges of financing a comfortable retirement?

In a DB world, it is relatively easy to measure the contribution from DB plans because, following retirement, DB plans typically provide a regular stream of income that can be successfully queried in surveys. The Current Population Survey (CPS) has questions about DB pension income as does the HRS, and such income is included in total income. But the DB world, while not at an end, is shrinking. Many more workers now have DC plans than DB plans, and additional workers and nonworkers have IRAs and Keogh accounts. Because annuitization of such plans (all of which we will refer to as "DC plans") is infrequent, asking about regular income from them to assess their support for consumption in retirement will underestimate their contribution. See Iams and Purcell (2013) for an assessment based on the Survey of Income and Program Participation (SIPP).

Some retirees make irregular withdrawals from DC plans; but apparently many others do not until they reach age $70^{1} / 2$ when they must take a mandatory distribution. Capturing these 
irregular withdrawals in a household survey is difficult, which likely has led to an underreporting of them in the CPS and, possibly, in the HRS.

Bee and Mitchell (2017) linked household data from the CPS with administrative data from the Internal Revenue Service (IRS), which recorded actual distributions from retirement accounts. They found that the CPS substantially under-measures retirement distributions when compared with IRS data. The underreporting came mainly from underreporting of retirement income from defined benefit pensions and from retirement account withdrawals such as distributions from DC accounts. The discrepancy between the CPS and the IRS data has increased over time.

In this paper, we use data from the 2014 wave of the Health and Retirement Study (HRS) to assess the importance of irregular withdrawals from pensions and individual retirement accounts to complement retirement income. To this end, we use data from the survey module on pensions that HRS substantially restructured starting with the 2012 data collection. Because the resulting data is quite different from previous HRS data on pensions, we include a description of the workings of this revamped section and some indicators of data quality.

\section{HRS Data on Pension Withdrawals}

Prior to 2012, HRS collected data on (regular) pension income, annuity income, and withdrawals from IRAs/KEOGHs. It also asked about the disposition of DC plans on termination of employment, to change jobs, or to retire. It did not query in a systematic way about irregular withdrawals from "dormant" DC plans, that is, from plans from prior employment that remained with the prior employer. For example, the HRS would not capture the irregular withdrawals by a 75 year old from a DC plan administered by a former employer. 
(If that same DC plan were rolled into an IRA, the HRS would capture withdrawals from the IRA.)

In 2012, the HRS revamped its pension section. It took a detailed inventory of all pensions whether current or inactive. It gave names to each pension with the objective of being able to ask about the disposition of each plan in future waves. It elicited the characteristics of each pension such as type, whether it was in pay status, if so, amounts of any regular benefits or payments, and if not, expected future benefits. It also queried about irregular withdrawals since separation from a former employer, but not in a manner permitting dating of the withdrawal. It is thus possible to form an inventory of pensions based on the HRS 2012 data, but because the date of the withdrawal was not captured, not an annualized total of money flows out of the pension plans. These queries are at the plan level which can be aggregated to the respondent level, and, in a coupled household, one can form an inventory of the household's pension holdings.

In 2014, the HRS further modified the pension instrument to account for the restructuring of the 2012 pension module in the context of a longitudinal survey. Because of the complete accounting of pension holdings undertaken in 2012, the HRS was able to ask about withdrawals from each pension since the last HRS interview in 2012 on a pension-by-pension basis. In principle, one can capture all extracts from tax-advantaged accounts between the 2012 HRS interview and the 2014 interview.

\section{Extracting Irregular Withdrawals from Pensions based on HRS Section J2}

Our strategy is to begin with HRS 2014 Section J2 which asks about all types of pension entitlements. There are two types of observations in Section J2: those with preloads about pensions as reported in $\mathrm{J} 2$ in 2012, and those without preloads because they were not interviewed 
in HRS 2012. Among those with preloads, HRS asks, pension plan by pension plan, whether it is still owned. If the plan is no longer owned then follow-up questions establish what happened to the plan. If the plan is still owned then payment status is queried. In both cases HRS takes care to distinguish irregular withdrawals from regular pension income, which is already included in the HRS measure of income. For this study, we account for all irregular pension withdrawals since last interview. We annualize the reported amounts by dividing by the number of years since the last interview, which is two for the vast majority of respondents having participated in adjacent waves. ${ }^{1}$

Among those without preloaded pension plans in 2014, the HRS first inventories respondents' pension holdings plan by plan and then asks the same questions about what happened to plans no longer owned, and the payment status of the plans still owned. Again, we extract all reported irregular withdrawals. One complication is that, because this group did not complete the new pension section $\mathrm{J} 2$ in 2012 , the time frame over which the reported withdrawals occurred may span several years (e.g., "since you left that employer") and the questionnaire does not ask any additional questions to narrow down the timing. As an approximation, we annualize the amounts by dividing by the number of years since last interview. While imperfect, this affects fewer than five percent of pension plans with irregular withdrawals.

HRS records the pension information at the pension plan-person-level. We conducted several data quality checks on the pension data, which we included in the Appendix. Here we report those findings most pertinent to this study.

\footnotetext{
${ }^{1}$ Due to variation in interview dates and length in field period the distance between interviews in adjacent waves can be less than two years and up to three years for some respondents.
} 
Rates of item nonresponse on the amount of irregular withdrawals averaged 15 percent. The survey instrument did not include any unfolding bracket questions if the amount was not reported. We imputed missing amounts using a nearest neighbor approach to preserve the covariance between pensions and other covariates. The amount imputations were performed at the person-plan level using an inverse hyperbolic sine transformation on the dependent variable (annualized amount of irregular withdrawal). In the nearest neighbor approach, we compute predicted values for all pension plans, both those with and without exact amounts. For each plan missing an exact value, we find the plan that is closest in predicted values among the plans where an exact amount has been reported. We then impute the actual value reported by the nearest neighbor.

Covariates in the amount imputation process are comprised of 10 principal components of approximately 20 underlying variables, including age and its square, gender, nonwhite race/ethnicity, marital status, education (college graduate or high school/GED), health status (excellent or poor), job occupation, employment status (working, disabled, unemployed, retired), bequest expectations $(\$ 10,000+$ or $\$ 100,000+)$, cognition, number of recorded pension plans, and number of years in the workforce. Although the covariates have systematic influence on the predicted values (R-squared about 0.14 ) the imputations will be imprecise because, unlike most other HRS monetary variables, there were no follow-up brackets for the amount of withdrawal.

In HRS 2014, there were 7,957 unique respondents with a record in the pension section (J2) data module. For 833 of these, or 10.5 percent, we identified one or more irregular withdrawals from a pension plan. The total number of plans with a recorded, irregular withdrawal was 908 , of which 85 percent included the amount. For the 15 percent of plans where the withdrawn amount was not reported, we performed imputations. Table 1 shows the 
distribution of the reported amounts at the plan level with a mean of $\$ 21,000$ and a median of $\$ 6,000$ prior to imputation. Post-imputation the distribution is very similar. There were three extreme values among the reported withdrawal amounts, one of which was imputed to another plan as part of the nearest neighbor imputation. After imputation and prior to any other analyses, we winsorized the four highest values as they had an outsized impact on the mean.

Summary statistics at the respondent-level are shown in Table 2. Among all respondents interviewed in HRS 2014, 4.4 percent have a recorded pension withdrawal amounting to $\$ 760$ on average across all respondents. While this suggests only a modest impact on total income in the population, the amounts can be substantial at the individual level: Among those who made pension withdrawals, the median amount is $\$ 6,500$ and the $99^{\text {th }}$ percentile is $\$ 175,000$.

\section{HRS Data on IRA and Keogh Withdrawals}

The HRS elicits information on whether households own any individual retirement and Keogh accounts and asks related follow-up questions in the Asset and Income section (Section Q) of the survey. In married or partnered households, the financial respondent answers all questions in this section on behalf of both the respondent and spouse. After eliciting ownership of IRA accounts, the survey asks about the total number IRA/Keogh accounts the household owns. In couples, it also queries who owns the respective accounts, and the balance in up to three accounts. If the household owns more than three accounts, then the third amount reflects the sum of all other accounts. Turning to withdrawals from IRA and Keogh accounts, the survey asks separately about the withdrawals from each account since last interview (or in last 24 months in case of new interviews), whether any withdrawals were made and, if so, the frequency of withdrawal(s). Should the amount be missing, the financial respondent is asked a sequence of 
unfolding brackets. For details on data quality and imputations, please see Hurd et al. (2018). Table 3 reports respondent-level summary statistics. In HRS 2014, 12.8 percent of respondents made withdrawals from IRA or Keogh accounts, amounting to $\$ 1,331$ on average. Conditional on making a withdrawal, the average amount is $\$ 10,400$ and the median is $\$ 4,615$. While the amounts may be modest at the population-level, for some individuals the amounts are substantial as evidenced by the amount associated with the $99^{\text {th }}$ percentile of withdrawal amounts $(\$ 81,379)$.

\section{Results}

We undertake two main comparisons. The first compares income measured in the CPS with income measured in HRS both before and after augmentation for IRA withdrawals and irregular withdrawals from DC-type accounts. The second compares the main measure of income in the HRS (which differs somewhat from that used in the CPS comparison) with that measure after augmentation.

The main measure of income in the HRS is called HwITOT under the RAND HRS naming convention where ' $w$ ' indicates the wave. Thus, income in 2014 is labeled H12ITOT because it was elicited in HRS wave 12. In general, H12ITOT includes the same types of income as in the CPS. Of particular note for this paper, is that both CPS and HRS include pension and annuity income, so we expect that both would include DB pension benefits, and, most likely, flows from DC accounts that are "regular," such as a standing order to send monthly a check from a DC account. It is likely that respondents would exclude irregular withdrawals, and, indeed, HRS specifically excludes lump-sum payments from retirement accounts. However, the HRS income measure differs from the CPS measure in several respects: It includes the cash equivalent of food stamps; it measures gross Social Security income rather than subtracting out withholdings for 
Medicare Part B; it does not include income of household members beyond the income of the HRS respondent and spouse or partner (if any). The RAND HRS includes an income measure that has made the adjustments to make the income measure equivalent to the CPS measure; it is called H12POVHHI in wave 12. We use H12POVHHI in our comparison with CPS income.

Table 4 shows mean and median CPS income, equivalently measured HRS income, and equivalently measured and augmented HRS income. The first two panels show incomes of households of married (or partnered) persons and single persons; the last four panels disaggregate single person households into several types according to whether additional people are present. We have followed CPS definitions to make them comparable. One possible point of error comes from assigning a personal attribute such as age to a household. The CPS has the concept of the "householder," which relates to the owner or renter of the dwelling. The HRS does not have that concept. In the case of an HRS couple, we assume that the oldest person corresponds to the householder (which often is the husband) and use that person's age as the age of the household.

Among couples, HRS income is in all instances greater than CPS income. For example, among 55 to 59 year olds, CPS median income was $\$ 94,671$; HRS median income was $\$ 107,000$, or 13 percent greater. The difference in mean income is greater still, about 27 percent greater. Except for persons 55 to 59, among singles, HRS median and mean income, are greater than CPS income, sometimes by substantial amounts.

It is not surprising that HRS income is greater than CPS income: That has been found before, and several reasons have been identified (Hurd, Juster and Smith 2003; Hurd and Rohwedder 2006). Beginning in 1996, HRS linked the query about income from assets to the query about asset amounts, which resulted in a substantial increase in dividend and interest 
income: Mean interest and dividends more than doubled between HRS 1994, which did not link, and 1996, which did link. CPS does not link. HRS uses a financial respondent to report on income and assets of a couple: The more knowledgeable person is likely to know about more sources of income. The CPS attempts to interview the "householder" (renter/owner of dwelling), but may take the interview from someone else. The HRS uses brackets which permits unsure or suspicious respondents to report a range of values. Bracketing is important among higher income individuals because covariates have limited explanatory power to produce large predicted values.

Among single persons, HRS income is greater than CPS income except for ages 55 to 59 . However, among sub-types of single households (last four panels) the discrepancy between CPS income and HRS does not show a consistent pattern. One reason is the small sample size in the HRS for those types of households. A second is that HRS spends considerably more interview time collecting data on the income of the HRS respondent and spouse and relatively less on the incomes of other family members.

The right-most columns show HRS total household income augmented by IRA withdrawals and by estimated irregular withdrawals from DC-type accounts. These are population medians and means, i.e. taken over those who withdrew and those who did not withdraw. The effect of the augmentation is noticeable, but highly variable depending on age. For example, among couples ages 55 to 59 median income increased from $\$ 107,000$ to $\$ 108,000$, an increase of 0.9 percent, and mean income from $\$ 153,736$ to $\$ 155,254$, an increase of 1.0 percent. Among couples 75 or older, the increases in the population median and mean are 8.4 percent and 8.6 percent respectively. 
Table 5 has a more compact way of showing the comparison between CPS and HRS. It has the percentage difference between HRS and CPS means and medians, columns (1) and (2); percentage difference between HRS and CPS means and medians when HRS income is augmented, columns (3) and (4); and the increase in the percentage difference in the last two columns. For example, among couples ages 55 to 59, before augmentation median HRS income is 13.0 percent greater than median CPS income; after augmentation, the HRS median is 14.1 percent greater for an increase of 1.1 percentage points. Among single persons ages 55 to 59 HRS median and mean income is less than the CPS medians and means. Irregular withdrawals reduce the gap, but do not close it. At older ages, especially at the mean, HRS income is considerably higher than CPS income, and irregular withdrawals increase the difference.

Because of differences in measurement and possibly for other reasons, HRS and CPS income differ, and sometimes by substantial amounts. It would, therefore, seem more fruitful to study the effect of irregular withdrawals by comparisons of income and augmented income within the HRS. Doing so has the further advantage that it focuses on the best-measured income measure in the HRS, income of the respondent and spouse.

Table 6 shows in the columns "HRS income" the median and mean incomes of respondent and spouse in the case of couples, and of the respondent in the case of single persons. A comparison of Table 4 (HRS Total household income) and Table 6 (HRS income) shows the combined effects of the included and excluded items. Among both couples and single persons, the CPS-type measure from Table 6 is higher, by 5 to 10 percentage points in the case of couples, and by 14 to 32 percentage points in the case of single persons.

In Table 6, augmented income is shown in the middle columns and the median and mean amounts of IRA and of irregular DC withdrawals are shown in the right columns. These are 
population medians and means, including those who did not make withdrawals. The medians of IRA and DC withdrawals are all zero because fewer than half of HRS households make such withdrawals. The means are substantial, however, and in some cases, the sum of the two reaches about $\$ 6,000$. IRA withdrawals tend to be highest after individuals have reached the age when distributions become mandatory, that is, after age 70 1/2. Pension withdrawals tend to be highest among those in their $60 \mathrm{~s}$, most likely because the withdrawals mainly take place on retirement.

The percentage increases in income from the irregular withdrawals are shown in Table 7. During the late 50s, when most are still working, the impact on income is minimal; but at 65 or older when retirement assets can be expected to be used for spending, the impact is to increase income by 4 to 10 percent among couples, and by 5 to 11 percent among single persons.

Because the required minimum distribution must first be taken during the year in which someone turns $70 \frac{1}{2}$, we also analyzed the age band 72 to 77 (Table 8 ). Among couples, the augmentation increased the median and mean by 10.1 and 8.9 percent respectively; among singles, the increases were somewhat smaller.

The preceding tables showed results for the household, using household weights and classifying according to the age of the older person in the case of couples. We now present results at the individual level using, in the case of couples, the characteristics of each spouse, and using person weights. Thus, the entries will show the income of the household in which a person with the specified characteristic lives. In the case of couples this will result in an approximate doubling of the number of observations, as the income of the household will enter the table under the characteristic of the husband, and also enter the table under the characteristic of the wife.

Table 9 shows the effect among those 65 or older of irregular withdrawals by wealth quartiles and by education. Among couples, irregular withdrawals increase median income in 
the highest wealth quartile by 12.3 percent, but just by 2.8 percent in the lowest quartile. Qualitatively this is to be expected because higher lifetime incomes lead to both higher saving rates outside of tax-advantaged accounts, and to a greater tendency to save via IRAs and optional DC accounts. Further, high income jobs are associated with pension plans, most of which are DC plans. The increase with wealth quartile is especially sharp for median, irregular withdrawals among singles: At the lowest wealth quartile there are hardly any irregular withdrawals, yet at the highest quartile irregular withdrawals increase median income by 15.3 percent. For both couples and singles, the increase in income associated with irregular withdrawals is flattened out at the mean. The patterns with respect to education are similar to those with respect to wealth quartiles: sharply increasing median income, less so for mean income.

Table 10 has the same information except that it pertains to those 75 or older. The general patterns are the same with irregular withdrawals having a greater impact at higher wealth quartiles, and among those with higher education.

Because of the strong correlation between wealth quartiles and the impact of irregular withdrawals, we would not expect that poverty rates would be highly affected by the inclusion of irregular withdrawals, and, indeed, the impact on poverty rates is minimal (Table 11). In many of the household cells of the table it is zero. A modest effect is found among single persons where the poverty rate declines from 17.0 percent to 16.4 percent, a change of 0.6 percentage points, when irregular withdrawals are added to conventionally measured income. 


\section{Conclusions}

In this paper, we sought to quantify the importance of irregular withdrawals from DC pensions and IRAs by comparing them to the incomes of older households. These irregular withdrawals are difficult to capture in household surveys. With the restructuring of the HRS pension section the tracking of pension balances and withdrawals was improved. Based on HRS 2014, irregular withdrawals from pensions and IRAs amounted to $\$ 2,049$ for singles and $\$ 6,663$ for couples on average among those 55 and older, but they are zero at the median. Among those making withdrawals, the average amount is $\$ 17,000$ for pension withdrawals and $\$ 10,400$ for IRA withdrawals. Pension withdrawals tend to be highest among those in their 60s, most likely because the withdrawals mainly take place on retirement; IRA withdrawals tend to be highest after individuals have reached the age when distributions become mandatory, that is, after age 70 1/2. The sum of mean irregular IRA and pension withdrawals is about 5 percent of mean income of singles and 10 percent of mean income of married households. The irregular withdrawals are concentrated among those in the highest wealth quartile and those in the highest education group, reflecting the higher prevalence of pensions in high-paying jobs that are predominantly held by those with high education. Because the withdrawals are heavily skewed toward high SES individuals, accounting for them has little impact on estimates of the poverty rate. 


\section{References}

Bee, Adam and Joshua Mitchell. 2017. "Do Older Americans Have More Income Than We Think?” SESHD Working Paper \#2017-39.

Hurd, M. D., E. Meijer, P. Pantoja and S. Rohwedder. 2018. "Addition to the RAND HRS Longitudinal Files: IRA Withdrawals in the HRS, 2000-2014,” MRRC Working Paper.

Hurd, M. D. and S. Rohwedder. 2006. “Consumption and Economic Well-Being at Older Ages: Income-and Consumption-Based Poverty Measures in the HRS.” Michigan Retirement Research Center, Working Paper 2006-110

Hurd, M. D., Juster, F. T. and Smith, J. P. 2003. "Enhancing the Quality of Data on Income: Recent Innovations from the HRS,” Journal of Human Resources, 38 (3), pp. 758-772.

Iams, Howard M. and Patrick J. Purcell. 2013. “The Impact of Retirement Account Distributions on Measures of Family Income” Social Security Bulletin, Vol. 73, No. 2. 
Table 1. Pension withdrawal amounts, conditional on any withdrawal, plan level, unweighted

\begin{tabular}{lcccccccccc}
\hline Amount (\$) & N & Mean & $\begin{array}{c}\text { Std } \\
\text { Dev }\end{array}$ & Min & P1 & Q1 & Median & Q3 & P99 & Max \\
\hline Pre-impute & 759 & 21,339 & 118,770 & 1 & 150 & 2,400 & 6,000 & 15,000 & 175,000 & $2,654,471$ \\
Post-impute & 908 & 21,780 & 118,204 & 1 & 150 & 2,500 & 6,000 & 15,000 & 166,667 & $2,654,471$ \\
\hline
\end{tabular}

Notes: Based on HRS 2014 data. 3 extreme values reported (see Max). One is picked as nearest neighbor in imputation. All 4 extreme values are winsorized after imputation, prior to further analysis.

Table 2. Frequency and amounts of pension withdrawals, HRS 2014, respondent-level, unweighted

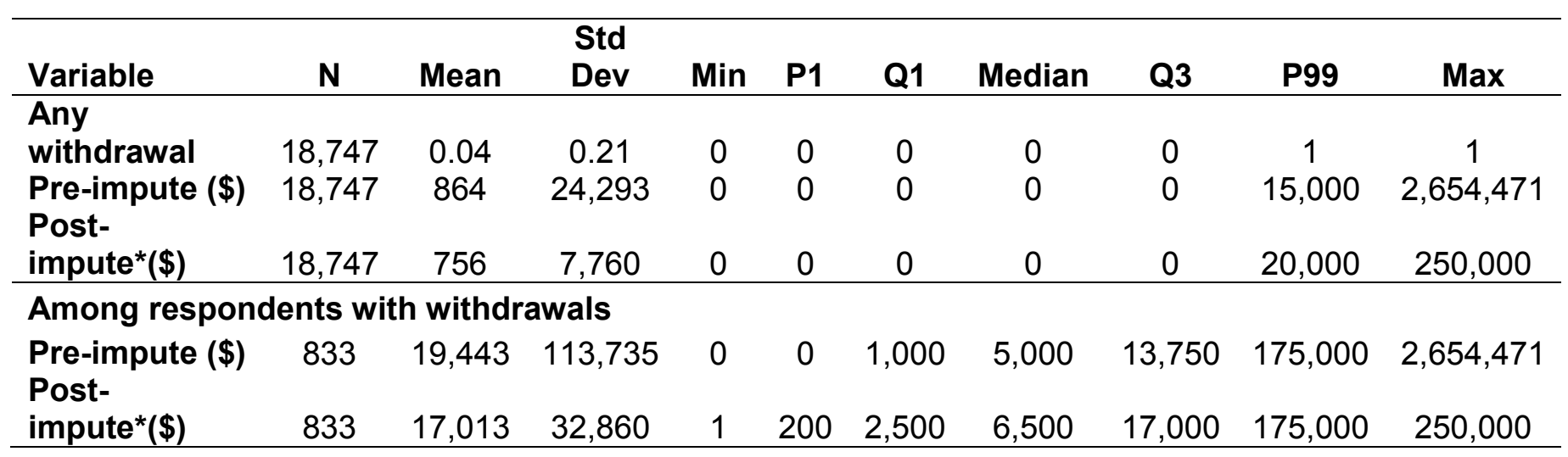

*Post imputations and post-winsorizing of the 4 largest, extreme values. 
Table 3. Frequency and amounts of IRA/Keogh withdrawals, HRS 2014, respondent-level, unweighted

\begin{tabular}{|c|c|c|c|c|c|c|c|c|c|c|}
\hline Variable & $\mathbf{N}$ & Mean & $\begin{array}{l}\text { Std } \\
\text { Dev }\end{array}$ & Min & $\mathbf{P 1}$ & Q1 & Median & Q3 & P99 & Max \\
\hline \multicolumn{11}{|l|}{ Any } \\
\hline Amount (\$) & 18,747 & 1,331 & 7,605 & 0 & 0 & 0 & 0 & 0 & 29,895 & 350,946 \\
\hline \multicolumn{11}{|c|}{ Among respondents with IRA/Keogh withdrawals } \\
\hline Amount (\$) & 2,400 & 10,400 & 18,909 & 4 & 83 & 1,778 & 4,615 & 11,453 & 81,379 & 350,946 \\
\hline
\end{tabular}


Table 4. Income in 2013 in CPS, total household income in HRS, and total household income in HRS augmented by irregular withdrawals from IRAs and DCtype pension accounts

\begin{tabular}{|c|c|c|c|c|c|c|c|c|c|}
\hline \multirow[b]{2}{*}{ Age } & \multirow[b]{2}{*}{$\mathbf{N}$} & \multicolumn{2}{|l|}{$\underline{\text { CPS }}$} & \multicolumn{3}{|c|}{$\begin{array}{c}\underline{\text { HRS Standard }} \\
\text { Total household income }\end{array}$} & \multicolumn{3}{|c|}{$\begin{array}{c}\text { HRS Augmented } \\
\text { Total household income }+ \\
\text { withdrawals (IRAs \& } \\
\text { Pensions) }\end{array}$} \\
\hline & & Median & Mean & $\mathbf{N}$ & Median & Mean & $\mathbf{N}$ & $\begin{array}{l}\text { Pensions } \\
\text { Median }\end{array}$ & Mean \\
\hline \multicolumn{10}{|c|}{ Married persons } \\
\hline $55-59$ & 6,517 & 94,671 & 121,219 & 1,253 & 107,000 & 153,736 & 1,253 & 108,000 & 155,254 \\
\hline $60-64$ & 5,688 & 80,784 & 107,626 & 1,235 & 93,740 & 130,816 & 1,236 & 100,000 & 135,563 \\
\hline $65-69$ & 4,825 & 67,440 & 97,191 & 858 & 79,757 & 122,158 & 858 & 83,660 & 127,223 \\
\hline $70-74$ & 3,606 & 60,148 & 80,184 & 864 & 65,434 & 97,203 & 865 & 72,050 & 103,160 \\
\hline $75+$ & 4,442 & 45,160 & 64,713 & 1,733 & 52,261 & 74,849 & 1,742 & 56,659 & 81,264 \\
\hline \multicolumn{10}{|c|}{ Single persons } \\
\hline $55-59$ & 5,448 & 34,036 & 51,703 & 1,219 & 31,396 & 47,008 & 1,219 & 32,080 & 48,515 \\
\hline $60-64$ & 4,681 & 31,647 & 46,696 & 1,106 & 32,001 & 70,778 & 1,106 & 34,400 & 72,955 \\
\hline $65-69$ & 4,157 & 30,393 & 42,641 & 679 & 35,000 & 59,626 & 679 & 38,300 & 62,760 \\
\hline $70-74$ & 3,181 & 26,630 & 37,303 & 845 & 31,279 & 57,572 & 845 & 33,559 & 60,083 \\
\hline $75+$ & 8,222 & 23,470 & 32,657 & 2,665 & 26,459 & 44,981 & 2,665 & 27,783 & 47,030 \\
\hline \multicolumn{10}{|c|}{ Male household with others, no spouse } \\
\hline $55-59$ & 507 & 54,039 & 76,289 & 174 & 34,000 & 52,927 & 174 & 35,000 & 53,231 \\
\hline $60-64$ & 233 & 47,192 & 67,580 & 100 & 32,680 & 75,661 & 100 & 40,120 & 78,974 \\
\hline $65-69$ & 239 & 50,276 & 58,958 & 44 & 56,019 & 56,274 & 44 & 56,019 & 58,565 \\
\hline $70-74$ & 105 & 36,792 & 70,099 & 54 & 41,375 & 52,539 & 54 & 41,375 & 54,625 \\
\hline $75+$ & 305 & 64,706 & 65,258 & 183 & 47,003 & 80,856 & 183 & 49,923 & 82,342 \\
\hline \multicolumn{10}{|c|}{ Female household with others, no spouse } \\
\hline $55-59$ & 1,236 & 45,582 & 73,551 & 435 & 35,001 & 51,163 & 435 & 35,001 & 51,976 \\
\hline $60-64$ & 849 & 43,026 & 50,875 & 373 & 42,328 & 57,495 & 373 & 45,500 & 59,941 \\
\hline $65-69$ & 683 & 44,222 & 59,368 & 212 & 44,403 & 78,188 & 212 & 47,422 & 82,229 \\
\hline $70-74$ & 495 & 46,998 & 57,975 & 242 & 41,835 & 66,371 & 242 & 42,359 & 67,853 \\
\hline $75+$ & 1,030 & 34,209 & 52,735 & 733 & 40,459 & 61,453 & 733 & 40,811 & 62,486 \\
\hline \multicolumn{10}{|c|}{ Male Alone } \\
\hline $55-59$ & 1,849 & 28,003 & 43,409 & 263 & 25,000 & 45,834 & 263 & 27,126 & 49,067 \\
\hline $60-64$ & 1,600 & 32,841 & 52,404 & 225 & 27,500 & 109,343 & 225 & 31,720 & 112,059 \\
\hline $65-69$ & 1,375 & 26,689 & 41,587 & 124 & 31,355 & 65,107 & 124 & 31,659 & 66,227 \\
\hline $70-74$ & 795 & 26,564 & 35,517 & 156 & 30,644 & 80,171 & 156 & 33,209 & 84,403 \\
\hline $75+$ & 1,718 & 24,660 & 37,502 & 422 & 28,061 & 44,521 & 422 & 30,545 & 48,637 \\
\hline
\end{tabular}


Female Alone

55 - $59 \quad 1,856$

$60-64 \quad 1,999$

26,893

38,699

347

30,036

41,315

347

30,168

42,403

$65-69 \quad 1,860$

24,047

37,919

$408 \quad 30,000$

51,366

408

30,480

52,658

70 - $74 \quad 1,786$

25,499

35,182

299

30,660

46,995

299

34,879

50,894

$75+$ 5,169

18,501

30,440

$393 \quad 25,259$

42,229

393

27,659

44,375

Note: HRS 2014 data, recording income for last calendar year (i.e. 2013). The HRS sample excludes

institutionalized households. HRS total household income (H12POVHHI) in this table from the most widely used

HRS measure of income (H12ITOT) by adjustments to match CPS definitions: the value of food stamps is excluded, Medicare Part B premiums are deducted from Social Security income, and income of other resident family members added in. See the RAND HRS codebook for complete definitions of H12ITOT and H12POVHHI. 
Table 5. HRS total household income relative to CPS: percent difference

\begin{tabular}{|c|c|c|c|c|c|c|}
\hline \multirow[b]{3}{*}{ Age } & (1) & (2) & (3) & (4) & $(3)-(1)$ & $(4)-(2)$ \\
\hline & \multicolumn{2}{|c|}{$\begin{array}{l}\text { HRS relative to } \\
\text { CPS }\end{array}$} & \multicolumn{2}{|c|}{$\begin{array}{l}\text { HRS including irregular } \\
\text { withdrawals relative to CPS }\end{array}$} & \multicolumn{2}{|c|}{$\begin{array}{l}\text { Difference in relative } \\
\text { percentages }\end{array}$} \\
\hline & Median & Mean & Median & Mean & Median & Mean \\
\hline \multicolumn{7}{|c|}{ Married persons } \\
\hline $55-59$ & 13.0 & 26.8 & 14.1 & 28.1 & 1.1 & 1.3 \\
\hline $60-64$ & 16.0 & 21.5 & 23.8 & 26.0 & 7.7 & 4.4 \\
\hline $65-69$ & 18.3 & 25.7 & 24.1 & 30.9 & 5.8 & 5.2 \\
\hline $70-74$ & 8.8 & 21.2 & 19.8 & 28.7 & 11.0 & 7.4 \\
\hline $75+$ & 15.7 & 15.7 & 25.5 & 25.6 & 9.7 & 9.9 \\
\hline \multicolumn{7}{|c|}{ Single persons } \\
\hline $55-59$ & -7.8 & -9.1 & -5.7 & -6.2 & 2.0 & 2.9 \\
\hline $60-64$ & 1.1 & 51.6 & 8.7 & 56.2 & 7.6 & 4.7 \\
\hline $65-69$ & 15.2 & 39.8 & 26.0 & 47.2 & 10.9 & 7.3 \\
\hline $70-74$ & 17.5 & 54.3 & 26.0 & 61.1 & 8.6 & 6.7 \\
\hline $75+$ & 12.7 & 37.7 & 18.4 & 44.0 & 5.6 & 6.3 \\
\hline \multicolumn{7}{|c|}{ Male household with others, no spouse } \\
\hline $55-59$ & -37.1 & -30.6 & -35.2 & -30.2 & 1.9 & 0.4 \\
\hline $60-64$ & -30.8 & 12.0 & -15.0 & 16.9 & 15.8 & 4.9 \\
\hline $65-69$ & 11.4 & -4.6 & 11.4 & -0.7 & 0.0 & 3.9 \\
\hline $70-74$ & 12.5 & -25.1 & 12.5 & -22.1 & 0.0 & 3.0 \\
\hline $75+$ & -27.4 & 23.9 & -22.8 & 26.2 & 4.5 & 2.3 \\
\hline \multicolumn{7}{|c|}{ Female household with others, no spouse } \\
\hline $55-59$ & -23.2 & -30.4 & -23.2 & -29.3 & 0.0 & 1.1 \\
\hline $60-64$ & -1.6 & 13.0 & 5.8 & 17.8 & 7.4 & 4.8 \\
\hline $65-69$ & 0.4 & 31.7 & 7.2 & 38.5 & 6.8 & 6.8 \\
\hline $70-74$ & -11.0 & 14.5 & -9.9 & 17.0 & 1.1 & 2.6 \\
\hline $75+$ & 18.3 & 16.5 & 19.3 & 18.5 & 1.0 & 2.0 \\
\hline \multicolumn{7}{|c|}{ Single male alone } \\
\hline $55-59$ & -10.7 & 5.6 & -3.1 & 13.0 & 7.6 & 7.4 \\
\hline $60-64$ & -16.3 & 108.7 & -3.4 & 113.8 & 12.8 & 5.2 \\
\hline $65-69$ & 17.5 & 56.6 & 18.6 & 59.2 & 1.1 & 2.7 \\
\hline $70-74$ & 15.4 & 125.7 & 25.0 & 137.6 & 9.7 & 11.9 \\
\hline $75+$ & 13.8 & 18.7 & 23.9 & 29.7 & 10.1 & 11.0 \\
\hline \multicolumn{7}{|c|}{ Single female alone } \\
\hline $55-59$ & 11.7 & 6.8 & 12.2 & 9.6 & 0.5 & 2.8 \\
\hline $60-64$ & 24.8 & 35.5 & 26.8 & 38.9 & 2.0 & 3.4 \\
\hline $65-69$ & 20.2 & 33.6 & 36.8 & 44.7 & 16.5 & 11.1 \\
\hline $70-74$ & 23.7 & 38.7 & 35.5 & 45.8 & 11.8 & 7.0 \\
\hline $75+$ & 14.1 & 33.0 & 22.6 & 40.5 & 8.5 & 7.5 \\
\hline
\end{tabular}

Note: See notes to Table 4. 
Table 6. HRS income with and without irregular IRA and DC withdrawals

\begin{tabular}{|c|c|c|c|c|c|c|c|c|c|}
\hline \multirow[b]{2}{*}{ Age } & \multirow[b]{2}{*}{$\mathbf{N}$} & \multicolumn{2}{|c|}{ HRS income } & \multicolumn{2}{|c|}{$\begin{array}{l}\text { HRS income plus } \\
\text { irregular IRA and } \\
\text { DC pension } \\
\text { withdrawals }\end{array}$} & \multicolumn{2}{|c|}{$\begin{array}{l}\text { Irregular IRA } \\
\text { withdrawals }\end{array}$} & \multicolumn{2}{|c|}{$\begin{array}{c}\text { Irregular DC-type } \\
\text { pension } \\
\text { withdrawals }\end{array}$} \\
\hline & & Median & Mean & Median & Mean & Median & Mean & Median & Mean \\
\hline \multicolumn{10}{|c|}{ Married persons } \\
\hline $55-59$ & 1,253 & 99,505 & 146,706 & 101,340 & 148,224 & 0 & 646 & 0 & 871 \\
\hline $60-64$ & 1,236 & 87,400 & 123,337 & 91,480 & 128,171 & 0 & 1,873 & 0 & 2,962 \\
\hline $65-69$ & 858 & 74,636 & 115,939 & 77,460 & 121,004 & 0 & 2,393 & 0 & 2,672 \\
\hline $70-74$ & 865 & 60,908 & 89,941 & 64,616 & 95,938 & 0 & 4,493 & 0 & 1,504 \\
\hline \multicolumn{10}{|c|}{ Single persons } \\
\hline $55-59$ & 1,219 & 25,200 & 39,554 & 26,000 & 41,061 & 0 & 197 & 0 & 1,310 \\
\hline $60-64$ & 1,106 & 25,050 & 62,357 & 27,500 & 64,534 & 0 & 934 & 0 & 1,243 \\
\hline $65-69$ & 679 & 27,007 & 51,909 & 30,096 & 55,042 & 0 & 1,660 & 0 & 1,474 \\
\hline $70-74$ & 845 & 24,080 & 47,099 & 25,644 & 49,611 & 0 & 1,999 & 0 & 513 \\
\hline \multicolumn{10}{|c|}{ Male household with others, no spouse } \\
\hline $55-59$ & 174 & 28,800 & 43,308 & 28,800 & 43,612 & 0 & 191 & 0 & 113 \\
\hline $60-64$ & 100 & 20,748 & 44,344 & 21,302 & 47,657 & 0 & 2,135 & 0 & 1,178 \\
\hline $65-69$ & 44 & 46,800 & 47,301 & 46,800 & 49,592 & 0 & 308 & 0 & 1,983 \\
\hline $70-74$ & 54 & 23,723 & 34,951 & 23,723 & 37,036 & 0 & 746 & 0 & 1,339 \\
\hline $75+$ & 183 & 20,640 & 52,416 & 21,600 & 53,903 & 0 & 1,289 & 0 & 198 \\
\hline \multicolumn{10}{|c|}{ Female household with others, no spouse } \\
\hline $55-59$ & 435 & 20,000 & 29,558 & 20,000 & 30,371 & 0 & 136 & 0 & 676 \\
\hline $60-64$ & 373 & 22,800 & 36,675 & 24,877 & 39,120 & 0 & 576 & 0 & 1,870 \\
\hline $65-69$ & 212 & 19,496 & 51,946 & 23,016 & 55,988 & 0 & 3,279 & 0 & 762 \\
\hline $70-74$ & 242 & 21,003 & 27,739 & 21,108 & 29,221 & 0 & 1,197 & 0 & 286 \\
\hline $\begin{array}{l}75+ \\
\text { Male Al }\end{array}$ & 733 & 16,260 & 25,910 & 16,980 & 26,943 & 0 & 964 & 0 & 69 \\
\hline $55-59$ & 263 & 26,551 & 45,806 & 27,126 & 49,039 & 0 & 190 & 0 & 3,043 \\
\hline $60-64$ & 225 & 27,500 & 110,313 & 31,687 & 113,028 & 0 & 982 & 0 & 1,733 \\
\hline $65-69$ & 124 & 30,096 & 64,122 & 30,400 & 65,242 & 0 & 299 & 0 & 822 \\
\hline $70-74$ & 156 & 29,400 & 78,919 & 31,950 & 83,152 & 0 & 3,629 & 0 & 603 \\
\hline $75+$ & 422 & 26,802 & 43,303 & 29,485 & 47,419 & 0 & 3,654 & 0 & 462 \\
\hline \multicolumn{10}{|c|}{ Female Alone } \\
\hline $55-59$ & 347 & 30,036 & 41,348 & 30,168 & 42,435 & 0 & 264 & 0 & 824 \\
\hline $60-64$ & 408 & 30,000 & 51,295 & 30,338 & 52,587 & 0 & 821 & 0 & 470 \\
\hline $65-69$ & 299 & 28,604 & 45,725 & 33,620 & 49,624 & 0 & 1,750 & 0 & 2,149 \\
\hline $70-74$ & 393 & 24,000 & 41,094 & 26,400 & 43,241 & 0 & 1,691 & 0 & 456 \\
\hline $75+$ & 1,327 & 20,124 & 32,304 & 21,580 & 34,193 & 0 & 1,765 & 0 & 123 \\
\hline
\end{tabular}

Note: HRS income (h12itot) is income of the HRS respondent and spouse (if a couple). It does not include income of other family members. See note to Table xx for other differences from CPS definitions. 
Table 7. Percentage increase in median and mean income associated with irregular IRA and DCtype pension withdrawals. HRS income

\begin{tabular}{|c|c|c|c|}
\hline & $\mathbf{N}$ & Median & Mean \\
\hline \multicolumn{4}{|c|}{ Married persons } \\
\hline $55-59$ & 1,253 & 1.8 & 1.0 \\
\hline $60-64$ & 1,236 & 4.7 & 3.9 \\
\hline $65-69$ & 858 & 3.8 & 4.4 \\
\hline $70-74$ & 865 & 6.1 & 6.7 \\
\hline $75+$ & 1,742 & 8.3 & 9.7 \\
\hline \multicolumn{4}{|c|}{ Single persons } \\
\hline $55-59$ & 1,219 & 3.2 & 3.8 \\
\hline $60-64$ & 1,106 & 9.8 & 3.5 \\
\hline $65-69$ & 679 & 11.4 & 6.0 \\
\hline $70-74$ & 845 & 6.5 & 5.3 \\
\hline $75+$ & 2,665 & 5.8 & 6.0 \\
\hline \multicolumn{4}{|c|}{ Male household with others, no spouse } \\
\hline $55-59$ & 174 & 0.0 & 0.7 \\
\hline $60-64$ & 100 & 2.7 & 7.5 \\
\hline $65-69$ & 44 & 0.0 & 4.8 \\
\hline $70-74$ & 54 & 0.0 & 6.0 \\
\hline $75+$ & 183 & 4.7 & 2.8 \\
\hline \multicolumn{4}{|c|}{ Female household with others, no spouse } \\
\hline $55-59$ & 435 & 0.0 & 2.8 \\
\hline $60-64$ & 373 & 9.1 & 6.7 \\
\hline $65-69$ & 212 & 18.1 & 7.8 \\
\hline $70-74$ & 242 & 0.5 & 5.3 \\
\hline $75+$ & 733 & 4.4 & 4.0 \\
\hline \multicolumn{4}{|c|}{ Male Alone } \\
\hline $55-59$ & 263 & 2.2 & 7.1 \\
\hline $60-64$ & 225 & 15.2 & 2.5 \\
\hline $65-69$ & 124 & 1.0 & 1.7 \\
\hline $70-74$ & 156 & 8.7 & 5.4 \\
\hline $75+$ & 422 & 10.0 & 9.5 \\
\hline \multicolumn{4}{|c|}{ Female Alone } \\
\hline $55-59$ & 347 & 0.4 & 2.6 \\
\hline $60-64$ & 408 & 1.1 & 2.5 \\
\hline $65-69$ & 299 & 17.5 & 8.5 \\
\hline $70-74$ & 393 & 10.0 & 5.2 \\
\hline $75+$ & 1,327 & 7.2 & 5.8 \\
\hline
\end{tabular}

Note: HRS income (h12itot) is income of the respondent and spouse (if a couple). It does not include income of other family members. See note to Table 4 for other differences from CPS income 
Table 8. HRS income and HRS income augmented by irregular withdrawals from IRAs and DCtype accounts. Ages 72 to 77

\begin{tabular}{lccccccc}
\hline & & \multicolumn{2}{c}{ HRS income } & \multicolumn{2}{c}{ HRS augmented income } & \multicolumn{2}{c}{ \% increase } \\
& N & Median & Mean & Median & Mean & Median & Mean \\
\hline Couples & 1,173 & 54,960 & 81,674 & 60,510 & 88,983 & 10.1 & 8.9 \\
Singles & 1,216 & 23,044 & 47,577 & 24,781 & 50,029 & 7.5 & 5.2 \\
\hline
\end{tabular}

Note: HRS income (h12itot) is income of the HRS respondent and spouse. It does not include income of other family members. See note to Table 4 for other differences from CPS income. 
Table 9. HRS income and percent increase when augmented with irregular withdrawals. Ages 65 or older

\begin{tabular}{|c|c|c|c|c|c|}
\hline & \multirow[b]{2}{*}{$\mathbf{N}$} & \multicolumn{2}{|c|}{ HRS income } & \multicolumn{2}{|c|}{$\%$ increase in median or mean } \\
\hline & & Median & Mean & Median & Mean \\
\hline \multicolumn{6}{|c|}{ Married persons } \\
\hline \multicolumn{6}{|l|}{ Wealth Quartile } \\
\hline Lowest & 1430 & 34,980 & 44,322 & 2.8 & 3.4 \\
\hline 2 & 1455 & 47,676 & 59,303 & 5.8 & 4.7 \\
\hline 3 & 1441 & 61,450 & 79,238 & 9.1 & 8.1 \\
\hline Highest & 1455 & 99,800 & 158,757 & 12.3 & 7.6 \\
\hline Total & 5781 & 58,500 & 89,719 & 8.8 & 6.8 \\
\hline \multicolumn{6}{|c|}{ Single persons } \\
\hline \multicolumn{6}{|l|}{ Wealth Quartile } \\
\hline Lowest & 946 & 13,680 & 18,205 & 0.4 & 0.7 \\
\hline 2 & 1077 & 17,954 & 23,646 & 1.7 & 2.1 \\
\hline 3 & 1090 & 24,000 & 32,067 & 5.8 & 5.8 \\
\hline Highest & 1076 & 41,040 & 79,124 & 15.3 & 7.4 \\
\hline Total & 4189 & 21,724 & 40,793 & 8.1 & 5.7 \\
\hline \multicolumn{6}{|l|}{ Married persons } \\
\hline \multicolumn{6}{|l|}{ Education Level } \\
\hline $\begin{array}{l}\text { 1.Lt High- } \\
\text { school }\end{array}$ & 951 & 31,746 & 41,173 & 2.2 & 3.9 \\
\hline $\begin{array}{l}\text { 2. HS } \\
\text { grad/GED }\end{array}$ & 2000 & 47,712 & 62,211 & 9.1 & 7.1 \\
\hline 3.Some college & 1317 & 61,390 & 85,381 & 8.2 & 7.3 \\
\hline $\begin{array}{l}\text { 4.College and } \\
\text { above }\end{array}$ & 1510 & 96,000 & 143,832 & 11.2 & 6.7 \\
\hline Total & 5778 & 58,500 & 89,733 & 8.8 & 6.8 \\
\hline \multicolumn{6}{|c|}{ Single persons } \\
\hline \multicolumn{6}{|l|}{ Education Level } \\
\hline $\begin{array}{l}\text { 1.Lt High- } \\
\text { school }\end{array}$ & 1067 & 13,240 & 19,602 & 1.5 & 2.6 \\
\hline $\begin{array}{l}\text { 2. HS } \\
\mathrm{grad} / \mathrm{GED}\end{array}$ & 1578 & 21,000 & 30,055 & 8.6 & 7.8 \\
\hline 3.Some college & 880 & 25,504 & 37,531 & 8.5 & 6.5 \\
\hline $\begin{array}{l}\text { 4.College and } \\
\text { above }\end{array}$ & 663 & 42,079 & 89,815 & 12.0 & 4.7 \\
\hline Total & 4188 & 21,724 & 40,796 & 8.1 & 5.7 \\
\hline
\end{tabular}

Note: HRS income (H12ITOT) is income of the HRS respondent and spouse. It does not include income of other family members. See note to Table 4 for other differences from CPS income. 
Table 10. HRS income and percent increase when augmented with irregular withdrawals. Ages 75 or older

\begin{tabular}{|c|c|c|c|c|c|}
\hline & \multirow[b]{2}{*}{$\mathbf{N}$} & \multicolumn{2}{|c|}{ HRS income } & \multicolumn{2}{|c|}{$\%$ increase in median or mean } \\
\hline & & Median & Mean & Median & Mean \\
\hline \multicolumn{6}{|l|}{ Married persons } \\
\hline \multicolumn{6}{|l|}{ Wealth Quartile } \\
\hline Lowest & 640 & 29,280 & 35,657 & 5.5 & 3.2 \\
\hline 2 & 648 & 39,328 & 49,318 & 5.2 & 4.5 \\
\hline 3 & 650 & 48,000 & 62,605 & 9.8 & 8.6 \\
\hline Highest & 657 & 79,915 & 110,813 & 18.2 & 13.9 \\
\hline Total & 2595 & 46,164 & 67,144 & 9.7 & 9.7 \\
\hline \multicolumn{6}{|l|}{ Single persons } \\
\hline \multicolumn{6}{|l|}{ Wealth Quartile } \\
\hline Lowest & 583 & 13,442 & 16,045 & 0.5 & 0.5 \\
\hline 2 & 683 & 16,728 & 21,140 & 2.4 & 1.3 \\
\hline 3 & 704 & 20,760 & 28,241 & 6.7 & 4.3 \\
\hline Highest & 695 & 37,132 & 60,871 & 12.4 & 9.0 \\
\hline Total & 2665 & 19,980 & 33,416 & 5.4 & 5.9 \\
\hline \multicolumn{6}{|l|}{ Married persons } \\
\hline \multicolumn{6}{|l|}{ Education Level } \\
\hline $\begin{array}{l}\text { 1.Lt High- } \\
\text { school }\end{array}$ & 501 & 30,876 & 37,033 & 2.3 & 5.4 \\
\hline $\begin{array}{l}\text { 2. HS } \\
\mathrm{grad} / \mathrm{GED}\end{array}$ & 946 & 40,728 & 53,256 & 8.6 & 9.6 \\
\hline \multirow{2}{*}{$\begin{array}{l}\text { 3. Some college } \\
\text { 4.College and } \\
\text { above }\end{array}$} & 518 & 51,180 & 73,702 & 11.0 & 8.2 \\
\hline & 629 & 75,852 & 100,457 & 12.2 & 11.6 \\
\hline Total & 2594 & 46,200 & 67,149 & 9.6 & 9.7 \\
\hline \multicolumn{6}{|l|}{ Single persons } \\
\hline \multicolumn{6}{|l|}{ Education Level } \\
\hline $\begin{array}{l}\text { 1.Lt High- } \\
\text { school }\end{array}$ & 727 & 13,683 & 17,877 & 1.2 & 2.3 \\
\hline $\begin{array}{l}\text { 2. HS } \\
\text { grad/GED }\end{array}$ & 1015 & 19,500 & 27,076 & 4.8 & 5.3 \\
\hline 3. Some college & 512 & 22,560 & 33,198 & 10.2 & 5.9 \\
\hline $\begin{array}{l}\text { 4.College and } \\
\text { above }\end{array}$ & 410 & 38,748 & 70,855 & 6.8 & 7.7 \\
\hline Total & 2664 & 19,980 & 33,420 & 5.4 & 5.9 \\
\hline
\end{tabular}

Note: HRS income (H12ITOT) is income of the HRS respondent and spouse. It does not include income of other family members. See note to Table 4 for other differences from CPS income. 
Table 11. Percent of population in poverty according to household income and household income augmented with irregular withdrawals

\begin{tabular}{lcccc}
\hline \multicolumn{1}{c}{ Age } & $\mathbf{N}$ & Household & $\begin{array}{c}\text { Income used } \\
\text { Augmented } \\
\text { household }\end{array}$ & $\begin{array}{c}\text { Difference in } \\
\text { rates }\end{array}$ \\
\hline Couples & & & 5.8 & -0.1 \\
$\mathbf{5 5 - 5 9}$ & 1253 & 5.9 & 6.4 & 0.0 \\
$\mathbf{6 0 - 6 4}$ & 1236 & 6.4 & 4.8 & -0.3 \\
$\mathbf{6 5 - 6 9}$ & 858 & 5.1 & 2.2 & 0.0 \\
$\mathbf{7 0 - 7 4}$ & 865 & 2.2 & 2.8 & -0.1 \\
$\mathbf{7 5}$ plus & 1742 & 2.9 & 4.7 & -0.1 \\
Total & 5954 & 4.8 & 23.2 & -1.3 \\
Singles & & & 20.6 & -0.9 \\
$\mathbf{5 5 - 5 9}$ & 1219 & 24.5 & 14.5 & -0.7 \\
$\mathbf{6 0 - 6 4}$ & 1106 & 21.5 & 10.6 & -0.1 \\
$\mathbf{6 5 - 6 9}$ & 679 & 15.2 & 12.9 & -0.2 \\
$\mathbf{7 0 - 7 4}$ & 845 & 10.7 & 16.4 & -0.6 \\
$\mathbf{7 5}$ plus & 2665 & 13.1 & 17.0 & \\
Total & 6514 & & & \\
\hline
\end{tabular}

Note: Household income in this table is total household income (h12povhhi). It includes adjustments to match CPS definitions: the value of food stamps has been excluded, Medicare Part B premiums have been deducted from Social Security income, and income of other resident family members added in. 


\section{Appendix}

\section{Appendix 1: HRS 2014 Pension Section}

The HRS redesigned the pension section (J2) with the objective to build a comprehensive inventory of all past and current pensions, establish which ones are still owned, and facilitate the linking of pension plans for each respondent over time.

The new design was first administered in HRS 2012. Preloads were created based on respondents' pension reports from previous HRS waves, which had followed a very different elicitation strategy. In 2012, a large fraction of preloaded plans were denied by respondents (about 30 percent of preloaded plans) and about 20 percent of respondents reported plans that had not previously been captured in a way to be entered into the preloads. This confirms that the pension information from prior waves was lacking information to link pension plans longitudinally.

For HRS 2014, the construction of preloads was based on the new inventory of pensions (or pension grid) obtained in 2012 that asked respondents to assign a name to each pension to facilitate the longitudinal tracking of pensions.

The data resulting from the HRS Pension Section J2 are recorded at the pension plan query-respondent level, that is each record represents a different pension plan query and more than one query can pertain to a single respondent. Most records are associated with different pension plan, but some records represent a plan query that was answered negatively. For example, a respondent who entered Section J2, but did not have any pension plan to report still has a record in the raw data even though it is not associated with any pension plan. Similarly, a separate record exists when a respondent was asked about "any other" plan and then answers no. 
In HRS 2014, a total of 7,957 respondents had at least one record in the pension module; of them, 6,432 has at least one preloaded pension plan. Because some respondents had multiple records (due to multiple plans, or a query for another plan which was then denied) there were 18,125 records in total in the pension module.

\section{Appendix Table 1. HRS 2014 pension module summary}

\begin{tabular}{llcc}
\hline $\begin{array}{l}\text { HRS 2014 pension } \\
\text { plan-level info }\end{array}$ & Count & $\begin{array}{c}\text { HRS 2014 Respondent } \\
\text { level info }\end{array}$ & Count \\
\hline Total records & 28,915 & Total records & 18,747 \\
In pension section & 18,125 & In pension section & 7,957 \\
In preload & 9,120 & In preload & 6,432 \\
\hline
\end{tabular}

To verify whether the longitudinal tracking of pension plans improved with the new pension section design we tabulated the fraction of previously reported plans as included in the preloads (Total $\mathrm{N}=9,120$ ) that were either confirmed or denied (App. Table 2). Only 4 percent of preloaded plans were denied in 2014, and 96 percent were confirmed by respondents. The majority of confirmed plans were still owned in 2014. This seems like a huge improvement compared to the plans that were preloaded in 2012. That said, those preloads were based on information not just from the preceding wave, but also on data from earlier waves.

\section{Appendix Table 2. Status of preloaded pension plans}

\begin{tabular}{lcc}
\hline Pension plan & N & $\%$ \\
\hline Confirmed, still owned & 7499 & 82.2 \\
Confirmed, no longer & 1225 & 13.4 \\
owned & 369 & 4.0 \\
Denied & 27 & 0.3 \\
Incomplete information & 9120 & 100.0 \\
All & \\
\hline
\end{tabular}




\section{Pension payment status and disposition}

For the purpose of this project the questions about what happened to a pension plan are particularly important and whether the respondent receives benefits, other payments from this plan or makes regular or irregular withdrawals. The answers are categorized as follows in the HRS data, allowing multiple mentions:

- Receiving regular payments/benefits;

- Left money in the account;

- Withdrew all of the money/received full amount as cash settlement or lump-sum;

- Withdrew some of the money;

- Rolled over into IRA;

- Converted to or purchased an annuity;

- Haven't done anything with plan/waiting to become eligible for benefits;

- Combined it with another plan;

- Transferred to new employer;

- Lost all benefits;

- Frozen, or lost some benefits;

- Other (specify).

Appendix Table 3 shows that for almost all plans the pension plan disposition is observed with few missing observations remaining. Among confirmed plans that respondents still own, 63 percent are not yet disbursing any money yet, which is similar to the 64 percent of newly reported plans. However, this rate is less than a half percent for confirmed plans that respondents no longer own. In this group 84 percent have a recorded disposition and for 9 percent of plans the respondent could not answer or said "other." 


\section{Appendix Table 3. Reported payment status of pension plans}

\begin{tabular}{|c|c|c|c|c|c|c|}
\hline \multirow{2}{*}{$\begin{array}{l}\text { Pension plan } \\
\text { disposition }\end{array}$} & \multicolumn{2}{|c|}{ Confirmed, still owned } & \multicolumn{2}{|c|}{ Confirmed, no longer owned } & \multicolumn{2}{|c|}{ Newly reported plan } \\
\hline & $\mathbf{N}$ & $\%$ & $\mathbf{N}$ & $\%$ & $\mathbf{N}$ & $\%$ \\
\hline \multirow{3}{*}{$\begin{array}{l}\text { Reported } \\
\text { DK/RF/Other only } \\
\text { Did not do } \\
\text { anything with plan } \\
\text { yet / waiting to } \\
\text { qualify for benefits }\end{array}$} & 2,666 & 35.55 & 1,031 & 84.16 & 433 & 34.12 \\
\hline & 90 & 1.20 & 112 & 9.14 & 29 & 2.29 \\
\hline & 4,735 & 63.14 & 5 & 0.41 & 806 & 63.51 \\
\hline Missing & 8 & 0.11 & 77 & 6.29 & 1 & 0.08 \\
\hline All & 7,499 & 100.00 & 1,225 & 100.00 & 1,269 & 100.00 \\
\hline
\end{tabular}

Notes: "Reported" includes all reported forms of benefit receipt or withdrawal. If R reports "left money in account" without any other form of benefit disbursement then the plan is coded as " $\mathrm{R}$ did not do anything with plan yet / waiting to qualify for benefits."

Additional/new plans reported in HRS 2014

As another data quality check we looked at how many additional plans were reported in 2014, some of which may have been missed in 2012. Among respondents who did not have any preloaded plans, 512 reported new plans; among the 6,432 respondents who did have preloaded plans 603 reported additional plans, so 90 percent did not report any additional plans beyond those that were preloaded.

\section{Appendix Table 4. Respondents with additional plans}

\begin{tabular}{|c|c|c|c|c|c|}
\hline $\begin{array}{l}\text { Has } \\
\text { preloaded } \\
\text { plans? }\end{array}$ & $\begin{array}{l}\text { Number of } \\
\text { non-preloaded } \\
\text { plans* }\end{array}$ & Frequency & Percent & $\begin{array}{l}\text { Cumulative } \\
\text { Freq }\end{array}$ & $\begin{array}{l}\text { Cumulative } \\
\text { Percent }\end{array}$ \\
\hline 0 & 0 & 11,803 & 62.96 & 11,803 & 62.96 \\
\hline 0 & 1 & 439 & 2.34 & 12,242 & 65.30 \\
\hline 0 & 2 & 63 & 0.34 & 12,305 & 65.64 \\
\hline 0 & 3 & 8 & 0.04 & 12,313 & 65.68 \\
\hline 0 & 4 & 2 & 0.01 & 12,315 & 65.69 \\
\hline 1 & 0 & 5,829 & 31.09 & 18,144 & 96.78 \\
\hline 1 & 1 & 539 & 2.88 & 18,683 & 99.66 \\
\hline 1 & 2 & 59 & 0.31 & 18,742 & 99.97 \\
\hline 1 & 3 & 5 & 0.03 & 18,747 & 100.00 \\
\hline
\end{tabular}




\section{Problems found in the HRS Pension Section (J2) and suggestions for improvement}

- Irregular withdrawals in Section J2 in 2012and 2014 are not expressly timebound (e.g., in the past two years) but rather are tied to 'since you left this job' or 'ever' (2012) or 'since last interview' (2012 for respondents who completed Section J2 in 2014).

Suggestion: At a minimum, add a question about withdrawals in last two years when the reference period would otherwise be longer (e.g., plans without preloads, often the wording is "since you left that employer ..." which can be longer for dormant plans; or when a respondent did not participate in the previous wave). If there is sufficient interest in the research community to obtain estimates for "last calendar year" to compare to HRS income measures, then this reference period query would need to be added as well.

- For irregular withdrawal amounts, no unfolding bracket questions are asked if the amount is missing. Imputation uncertainty is much larger in the absence of the bracket questions, and this effect is particularly large when the distribution of the underlying variable is highly skewed, as is the case with pension withdrawals.

Suggestion: Add unfolding brackets to the amount questions about irregular withdrawals in cases where an exact amount is not reported.

- Plan type is not reasked in subsequent waves, once reported for a plan in Section J2. For example, if plan type was reported in J2 in 2012, then it was not re-asked in J2 in 2014. However, respondents have difficulty reporting plan type accurately.

Suggestion: Re-ask pension plan type every wave.

- DB plans, once reported as "receive regular benefits" will not be queried as part of Section J2 in subsequent waves. It appears that the underlying assumption is that such regular benefits will be captured in the Asset and Income Section of the HRS going forward. However, it has proven difficult for respondents to accurately report the pension plan type as evidenced by inconsistent reports over time. This skip logic that relies on plan type propagates any misreporting forward: if the plan was not actually a DB plan, but a DC plan instead, then no further detailed questions will be asked about this plan in future waves. 
Furthermore, DB plans from which respondents report receiving regular benefits are not used to populate preloads for the next wave. However, when respondents are asked about any other plans they might have, they may re-report those plans and these would look like new plans, when in fact they are not.

Suggestion: Use all pension plans that are still active to construct the preloads for the next wave to ensure proper tracking of plans over time, and reduce the chances of doublecounting. 